\title{
Isparta Orman Bölge Müdürlüğü'nün Akdeniz iklimi etkisi altındaki Kızlçam (Pinus brutia Ten.) doğal gençleştirme sahalarında anakaya-toprak özelliklerinin ağaç gelişimine etkisi
}

\author{
Yasin Karatepe $^{a, *}$, Erdi Koyun ${ }^{\text {b }}$
}

\begin{abstract}
Özet: Bu çalışma Isparta Orman Bölge Müdürlüğü'nün Akdeniz iklimi etkisi altındaki kızılçam (Pinus brutia Ten.) doğal gençleştirme sahalarında anakaya- toprak özelliklerinin ağaç gelişimine etkisini belirlemek için gerçekleştirilmiştir. Bu amaçla 7 farklı doğal gençleştirme sahasında çalışma yapılmıştır. Çalışma 3 tekrarlı olarak gerçekleştirilmiştir. Bu sahalarda toprak profili incelenmiş olup 21 farklı örnek alanda $0-30 \mathrm{~cm}$ derinlik kademelerinden toprak örnekleri alınmıştır. Ayrıca her bir sahada koordinat, yükselti, bakı ve eğim ölçmeleri yapılmıştır. Her bir sahada $10 \times 3=30$ ağacın gögüs yüksekliği çapı ve boy uzunlukları ölçülmüss, ağaç yaşı belirlenmiştir. Laboratuvarda hava kurusu haline getirilen 21 toprak örneğinde; tane çapı, toprak reaksiyonu $(\mathrm{pH})$, organik karbon, toplam azot ve kireç analizleri yapılmıştır. İstatistiksel değerlendirmelerde göğüs yüksekliği çap ve boy değerleri 10 yaşa enterpole edilerek kullanılmıştır. Bulunan sonuçlar toprak özelliklerinin kızılçam gelişimine negatif ya da pozitif yönde bir etkisinin olmadığını göstermiştir. Anakaya farklılı̆ıının ise ağaç gelişimi üzerinde önemli bir etkiye sahip olduğu, bu etkinin ise tortul tabakalarının pozisyonuna göre değişen fizyolojik derinliğe ve konglomera gibi kayalarda ise tabaka pozisyonunun yanı sıra çakıl yoğunluğundan artan iskelet içeriğine bağlı olduğu belirlenmiștir.

Anahtar kelimeler: Kızılçam (Pinus brutia Ten.), Ağaç gelişimi, Toprak özellikleri, Anakaya yapısı
\end{abstract}

\section{Effects of soil-bedrock properties on tree growth in Red Pine (Pinus brutia Ten.) natural regeneration sites under the influence of Mediterranean climate in Isparta Regional Directorate of Forestry}

\begin{abstract}
This study was performed to determine the effect of soil-bedrock properties on growth of natural regeneration areas of Turkish red pine (Pinus brutia Ten.), which is distributes in sites with Mediterranean climate in Isparta Regional Directorate of Forestry. For this purpose, the study was conducted at 7 different site conditions within natural regeneration areas. The study was carried out with three replicates in all the areas. In these areas, the soil profiles were examined and soil samples were tak en from 0-30 cm in each sample plot. Also, values of coordinates, altitudes, aspects and slopes were measured and recorded at each plot . Breast-height diameter and height of $10 \times 3=30$ trees in each sample plot were measured and recorded. Soil texture, reaction $(\mathrm{pH})$, organic carbon, total nitrogen and lime analysis were performed on 21 soil subsamples, which were air-dried in the laboratory. Based on the information obtained, breast-height diameter and height of trees were interpolated according to stem analysis for the age of 10. Obtained results showed that there wasn't a negative or positive relationship between growth and soil properties. Bedrock variation has a significant impact on the growth of trees. This effect, besides the varying the position of the physiological depth of sedimentary layer and the position in rock layers as the conglomerate, was determined, it is linked to increased skeletal density of silica.
\end{abstract}

Keywords: Red pine (Pinus brutia Ten.), Tree growth, Soil properties, Bedrock structure

\section{Giriș}

Kızılçam, kuzey yarım kürede, yaklaşık $32^{\circ}-45^{\circ}$ kuzey enlemleri ile $15^{\circ}-45^{\circ}$ doğu boylamları arasında geniş bir bölgede yayılış göstermektedir (Kayacık, 1965). Bu tür genel olarak Doğu Akdeniz ülkelerinde yayılış yapmakta olup Akdeniz ikliminin tipik bir ağaç türüdür. $\mathrm{Bu}$ yayılışında en batı noktasını İtalya'daki Kalabriya Yarımadas1, en doğu noktası da Irak'ın kuzeyi olduğu belirtilmektedir (Asmaz, 1993). Özellikle Kibrıs ormanlarının \%90'ını kızılçam ormanları oluşturmaktadır (Pantelas,1986). Kızılçam (Pinus brutia Ten.) Türkiye'de en geniş yayılış alanına sahip asli ağaç türü olup, kızılçam ormanlarının kapladığ 1 alan 2.999.684,9 ha normal, $2.420 .839,7$ bozuk orman vasfinda olup, toplam olarak ise $5.420 .524,6$ ha büyüklüğündedir (Anonim, 2012). Bu alan Türkiye ormanlarının \% 25'ine tekabül etmektedir. Kızılçam, Genel yayılışını Akdeniz, Ege, Marmara, Trakya ve lokal olarak Karadeniz ile Güneydoğu Anadolu bölgelerinde yapmaktadır. Ceyhan nehri ile Malatya dolaylarında $200 \mathrm{~km}$, Gediz ile Ege'de $300 \mathrm{~km}$ içeriye sokulur. Siirt Eruh'ta ise 10-15 ha kadar lokal bir yayılışı vardır (Neyişçi, 1987a).

Kızılçam genel olarak yazları sıcak ve kurak, kışları 1lık ve yağışı olan Akdeniz iklimi bölgelerinde yayılış göstermektedir. Kızılçam sıcaklık isteği yüksek, donlara

\footnotetext{
a a Süleyman Demirel Üniversitesi, Orman Fakültesi, Orman Mühendisliği Bölümü, Isparta

b Orman Mühendisi, Antalya

@ ${ }^{*}$ Corresponding author (İletişim yazar1): yasinkaratepe @ sdu.edu.tr

$\checkmark$ Received(Geliș tarihi): 01.11.2016, Accepted(Kabul tarihi): 01.12.2016
}

Citation (Atıf): Karatepe, Y., Koyun, E., 2017. Isparta Orman Bölge Müdürlüğü'nün Akdeniz iklimi etkisi altındaki Kızılçam (Pinus brutia T en.) doğal gençleştirme sahalarında anakayatoprak özelliklerinin ağaç gelișimine etkisi, 2017. Turkish Journal of Forestry, 18(1): 30-36. DOI: $10.18182 /$ tif. 308632 
hassas ve karasal iklimlerden kaçınan bir türdür (Saatçioğlu ve Pamay, 1962). Kızılçam Akdeniz Bölgesi'nde; deniz seviyesinden başlayarak, meşcere halinde $1300 \mathrm{~m}$ ve tek ağaç olarak 1500 m’ye kadar çıabilmektedir. Akdeniz Bölgesi'nden kuzeye doğru gidildikçe çıkabileceği üst yükselti düşmektedir. Örneğin Ege Bölgesi'nde kızllçam 800-900 m, Marmara Bölgesi'nde ise 600-700 m'ye kadar çıkabilmektedir. Marmara ve Karadeniz Bölgelerinde kızılçamın ulaştığı en yüksek nokta Osmancık'ta 700 m'dir. Ege Bölgesinde ise Uşak dolaylarında 1100-1150 m'ye kadar çıkabilmektedir (Atalay, 1983).

Türün doğal yayılıș alanlarında yıllık ortalama sıcaklık $12-20^{\circ} \mathrm{C}$ arasında değişmekte olup, Ocak ayı ortalama sıcaklık $5-10^{\circ} \mathrm{C}$, bazı kuzey ve yüksek kesimlerde $3-4$ ${ }^{\circ} \mathrm{C}$ olup, $0{ }^{\circ} \mathrm{C}$ 'nin altına düşmemektedir. En düşük sıcaklık ise $4{ }^{\circ} \mathrm{C}$ ile $-11^{\circ} \mathrm{C}$ arasinda seyretmekte, $-15^{\circ} \mathrm{C}$ 'nin altına inmemektedir. Temmuz ayı ortalama sicaklık $23-28{ }^{\circ} \mathrm{C}$ arasında olup en yüksek sıcaklık ise $45^{\circ} \mathrm{C}$ ye ulașmaktadır (Atalay vd., 1998). Kızılçam yayılış alanlarında yıllık ortalama yağış $400 \mathrm{~mm}$ (Burdur, Mut) ile $2000 \mathrm{~mm}$ (Geyik dağları - Aydınkent) arasında seyretmektedir. Kızılçamın yayılış alanlarında yağışların yıl içerisindeki dağılımı düzensiz olup, önemli bölümü kış aylarına rastlamaktadır (Atalay vd., 1998). Cok düşük olan yaz yağıșları (200 mm'nin altında) kuzeye ve yüks eklere çıktıkça artmaktadır. Güneybatıya bakan ve bu yönden yağış getiren rüzgârları doğrudan alan yamaçlarda, yağıș miktarı daha yüksektir. Akdeniz bölgesinin denize bakan yamaçlarında, kıyıdan itibaren yüks eldikçe önce yağış artmakta, daha yukarılarda ise azalmaktadır (Kantarcı, 1982). Kızılçam yayılıșının sahil kușağında, yıllık ortalama bağıl nem \% 60 - 70 arasında olup, AkdenizBölgesi'nin bazı yörelerinin bağıl nemi, yazın kış aylarına göre daha yüks ektir. Yağışı düşük olduğu bazı yörelerde ve kıyı bölgelerinde, yazın yüksek bağıl nem terletmeyi azaltmaktadır. Vejetasyon döneminde bağıl nemin \% 50'nin altına düştüğü, örneğin Güneydoğu Anadolu Bölgesi'nin iç kısımlarında, Kızılçam iyi bir gelişme yapmamaktadır (Atalay vd., 1998). Akdeniz Bölgesi'nde, ilkbahar ve sonbaharda 3 - 4 gün ile $10-15$ gün arasında değişen sürelerde bölgeyi etkisi altına alan kuzey rüzgârları, bağıl nemi \% 0' a kadar düşürebilmektedir (Neyişçi, 1987b).

Quezell (1977), tarafindan yapılan çalışmada, kızılçamın toprak konusunda özel bir isteğinin olmadığ 1 ve gevşek toprakta olduğu kadar yüzeyi çatlaklı ya da kırılmış kayalar üzerinde de yetişebildiği belirtilmiştir. Kantarcı (1984), tarafindan yapılan çalışmada kızılçamın yetişme ortamlarında jeolojik temelin, genel olarak Mezozoik devrinin Jura ve Kratase Kalkerleri olduğu ve ayrıca fliş ve alüvyal depolar üzerinde de kızılçam meşcerelerine rastlandığ 1 belirtilmiştir.

Yukarıdaki paragraflarda doğal yayılış alanlarının yetişme ortamı özellikleri hakkında bilgi verilen kızılçam türü, Isparta Orman Bölge Müdürlüğü ormanlarının yaklaş k \% 38'inde saf orman niteliğinde yayılış göstermektedir. Yörede bu tür geniş alanlarda yayılmasının yanı sıra, hızlı gelişen bir tür olması sebebiyle Isparta Orman Bölge Müdürlüğü açısından önemli bir asli ağaç türüdür. Dolayısıyla bu türe iliş kin yapılan ya da yapılması planlanan çalışmaların hem lokal ölçekte, hem de ülke ormancilığ adına önemi büyüktür. Buradan hareketle bu çalışma ile Isparta Orman Bölge Müdürlüğü'nün Akdeniz İklimi etkisi altındaki kızılçam (Pinus brutia Ten.) doğal gençleştirme sahalarında anakaya-toprak özelliklerinin ağaç gelişimine etkisinin belirlenmesi amaçlanmış olup, elde edilen bilgilerin bu türe ilişkin ormancılık uygulamalarında faydalı olacağı öngörülmüştür.

\section{Materyal ve yöntem}

\section{1 Çalışma alanının konumu, jeolojik yapısı ve iklim özellikleri}

Çalş̧ma Isparta İli güneydoğusunda yer alan Aşağıgökdere Köyü'nün güneyinde gerçekleştirilmiştir. Çalışma alanı Aşağıgökdere Orman İşletme Şefliği sınırları içerisinde yer almaktadır. Araştırma alanı Batı Toros Dağları'nın deniz etkisi altındaki güney kesiminde, $30.7809^{\circ}$ - $30.8537^{\circ}$ doğu boylamları ile $37.5523^{\circ}$ $37.5712^{\circ}$ kuzey enlemleri aras inda bulunmakta olup yükselti 353 - $643 \mathrm{~m}$ arasında değişmektedir (Şekil, 1). Çalışma alanı ve çevresindeki yaygın anakaya grubunu konglomera, kum taş1, kiltaşı, kireçtaş1 gibi tortul kayaçlar ile doğuya doğru ofiyolitli melanjlar oluşturmaktadır (Şenel, 1997).

Çalışma alanı Akdeniz iklimi etkisi altındadır. Araştırma alanını en iyi temsil edebilecek ve sahaya en yakın olan Sütçüler meteoroloji istasyonu verilerine göre yıllık ortalama toplam yağış $905.2 \mathrm{~mm}$, en yüksek yağış 420.9 mm ile kışın (aralık-ocak-şubat) en düşük yağ $1 s ̧ 45.7$ mm ile yazın (temmuz-ağustos-eylül) düşmektedir. Y1llık ortalama sicaklik $13,0{ }^{\circ} \mathrm{C}$ 'dir. En sicak ay $24.0{ }^{\circ} \mathrm{C}$ ile temmuz, en soğuk ay ise $3.0^{\circ} \mathrm{C}$ ile ocak ayıdır. Thornthwaite yöntemine göre iklim tipi $B_{2} B_{1}{ }^{\prime} s_{2} b_{3}{ }^{\prime}$ simgesi ile gösterilen nemli, mezotermal, yazın çok kuvvetli su açığı olan ve deniz iklimi etkis ine yakın iklim tipidir (Karatepe, 2004).

\subsection{Yöntem}

Bu çalışma 7 kızılçam doğal gençleștirme sahasında gerçekleştirilmiş olup, sahaların her birisinde, mümkün olduğunca birbirine benzer özellikte olmak üzere 3'er adet, toplamda ise 21 tane örnek alan alınmıștır. Arazi çalışmalarında, her bir örnek alanın yüks eltisi, bakısı, eğimi, konumu ve koordinatları ile ilgili notlar alınmıştır. Yükselti altimetre, eğim klizimetre, bakı pusula, koordinatlar GPS ile belirlenmiștir. Belirlenen örnek alanlar içeris inde 10 ağacın gögüs yüks ekliği çap1 $\left(\mathrm{d}_{1,30}\right)$ (kabuklu) ve boyları ölçülerek kaydedilmiştir. Daha sonra her bir örnek alan için ortalama çap ve boya en yakın ağaç kesilerek, yaş tayini yapılmış ve laboratuvarda kabuksuz çapı belirlemek için gövde kesitleri alınmıștır. Her bir sahada en iyitemsil kabiliyetine sahip bir noktada, derinliğin yeterli olması durumunda $120 \mathrm{~cm}$ ye kadar toprak profili açılmış ve incelenmiştir. Ayrıca her bir örnek alanda da 0-30 cm derinlik kademesinden toprak örnekleri alınmıştır.

$\mathrm{Bu}$ çalışmada 21 toprak örneği üzerinde analizler gerçekleştirilmiştir. Topraklarda tane çapı (Bouyoucous hidrometre metodu ile), toprak reaksiyonu $\left(\mathrm{H}_{2} \mathrm{O}\right.$ ve $1 \mathrm{~N}$ KCl'de cam elektrotlu pH-metre ile), organik karbon (Walkley-Black is lak yakma yöntemi ile), toplam azot (sömi-mikro Kjeldahl metodu ile), kireç (Scheibler kalsimetre yöntemi ile), analizleri yapılmıştır (Karaöz, 1989a; 1989b) 


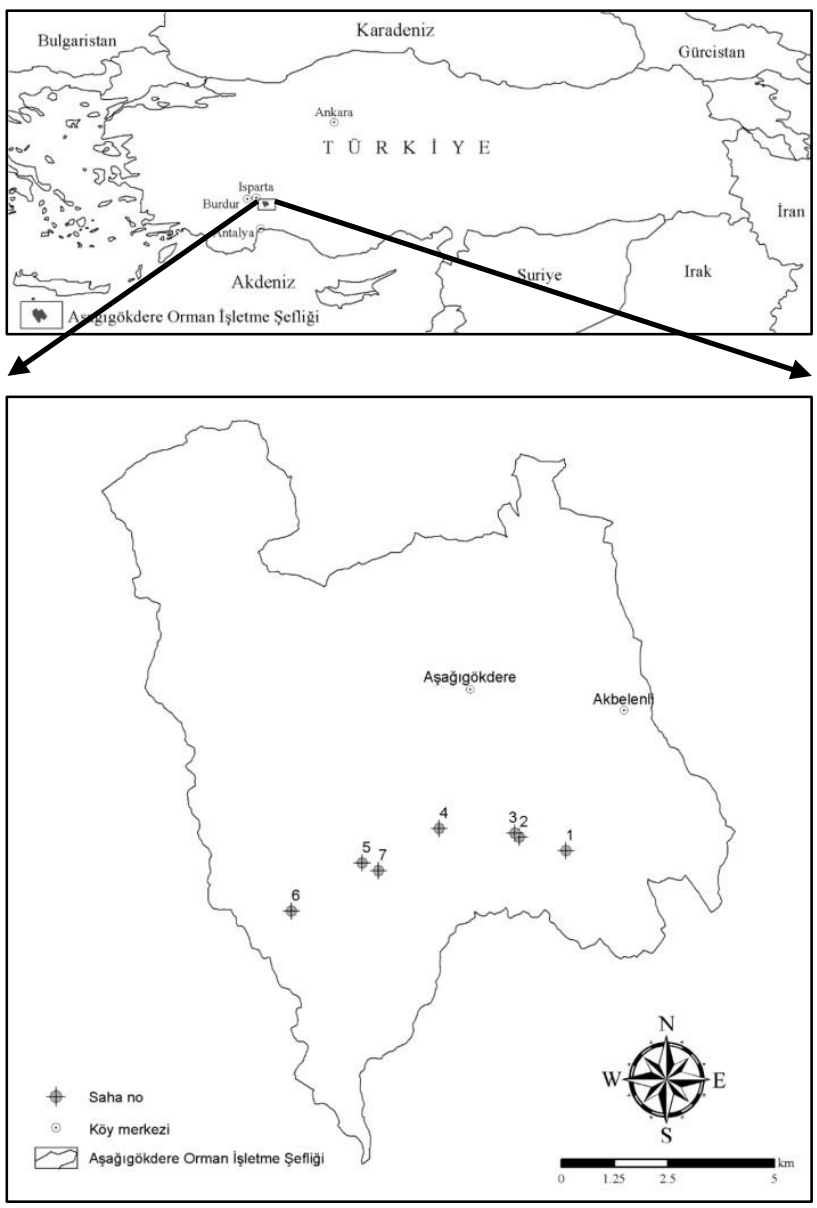

Şekil 1. Çalışma alanının konumu

Doğal gençleştirme sahalarında ölçülen göğüs yüksekliği çapı (kabuksuz) ve boy değerleri 10 yaşa enterpole edilmiş, istatistik analizlerinde bu değerler kullanılmıştır. Elde edilen veriler istatistiki açıdan SPSS paket programında değerlendirilmiştir. Varyans analizi ve Duncan testi ile 10 yaşındaki gögüs yüksekliği çap1 ve boy değerleri sahalar arasında karşılaştırılmıştır. Ayrıca toprak özellikleri (organik karbon, toplamazot, kireç, aktüel asitlik, potansiyel asitlik, kum içeriğ $i$, toz içeriği ve kil içeriği) ile gögüs yüksekliği çapı ve boy değerleri aras ındaki ilişkiyi ortaya koyabilmek için ise toplam 21 örnek alan için korelasyon analizi yapılmıştır. İstatistiki sonuçlar ekolojik olarak yorumlanmıştır.

\section{Bulgular}

\section{1. Örnek alanlara ilişkin arazi ve laboratuvar bulguları}

Örnek alanlarla ilgili olarak arazide yapılan ölçüm ve tespitlere göre yükseltinin 353-643 m ve eğimin 3-39 aras ında değiştiği belirlenmiştir (Çizelge 1). Örnek alanlarda yapılan anakaya tespitlerine göre çalışma alanında ras tlanan anakaya çeşitleri kiltaşı, kumtaşı, konglomera ve ofiyolitik melanj'dır. Torosların güney kesiminde yer alan çalışma alanında, örnek alanlarda tespit edilen bakı grupları güney, güneybat1, güneydoğu ve doğudur. Örnek alanların reliyef durumları alt yamaç, alt orta yamaç, üst orta yamaç, sırt düzlüğü olarak belirlenmiştir. Örnek alanlarda ölçümü yapılan ağaçlarla ilgili olarak, yaşın 7-19 aras ında değiştiği, 10 yaşa enterpole edilmiş kabuksuz çap değerleri ortalamasının $1,83-11,21 \mathrm{~cm}$ boy değerleri ortalamasının ise 2,59-7,81 m arasında değiştiği tespit edilmiştir. Örnek alanlara ilişkin bazı yetişme ortamı özellikleri, ağaç yaş1, gögüs yüksekliği çapı ve boy değerleri ayrıntılı olarak çizelgede gösterilmiştir.

Yapılan toprak analizleri sonucunda, topraklarm 0-30 cm derinlik kademesi için organik karbon miktarının; \% 0,359-2,727 arasında, toplan azot miktarının; \% 0,025-0,194 arasında, kireç içeriğinin; \% 0,00-40,58 arasında; aktüel as itliğ in; 7,12-8,14 pH değeri aras ında, potansiyel as itliğin; 6,37-7,71 pH değeri arasında, kum içeriğinin; \% 30,5-79,1 arasında, kil içeriğinin; \% 8,7-52,0 aras ında, toz içeriğinin; \% 2,1-41,0 arasında değiştiği belirlenmiştir (Çizelge 2). Toprak türü ağırlıklı olarak balçıklı kil olup, örnek alanlarda tespit edilen diğer toprak türleri; kil (ağır kil), killi balçık, kumlu kil, kumlu killi balçık ve kumlu balçıktır. Toprak özelliklerinin örnek alanlar bazındaki değişimi ayrıntılı olarak çizelgede gösterilmiştir.

Çizelge 1. Örnek alanların bazı yetişme ortamı özellikleri, ağaç yaşı, göğüs yüks ekliği çapı ve boyu (10yaş) değerleri

\begin{tabular}{|c|c|c|c|c|c|c|c|c|}
\hline $\begin{array}{l}\text { Örnek } \\
\text { alan no }\end{array}$ & $\begin{array}{l}\text { Yükselti } \\
(\mathrm{m})\end{array}$ & $\begin{array}{c}\text { Eğim } \\
\left({ }^{\circ}\right)\end{array}$ & Bak1 & Anakaya & Reliyef & $\begin{array}{c}\text { Ağaç yaşı } \\
(\text { y1l })\end{array}$ & $\begin{array}{l}\text { Çap } \\
(\mathrm{cm})\end{array}$ & $\begin{array}{l}\text { Boy } \\
\text { (m) }\end{array}$ \\
\hline $1-1$ & 634 & 15 & $\mathrm{G}$ & Ofiyolitik melanj & Alt orta yamaç & 9 & 5,88 & 4,41 \\
\hline $1-2$ & 637 & 17 & $\mathrm{G}$ & Ofiyolitik melanj & Alt orta yamaç & 9 & 5,56 & 4,31 \\
\hline $1-3$ & 643 & 19 & $\mathrm{G}$ & Ofiyolitik melanj & Üst orta yamaç & 9 & 5,67 & 4,54 \\
\hline $2-1$ & 541 & 17 & G & Kiltaşı & Alt orta yamaç & 12 & 6,72 & 4,24 \\
\hline $2-2$ & 546 & 19 & $\mathrm{G}$ & Kiltașı & Alt orta yamaç & 12 & 8,10 & 4,94 \\
\hline $2-3$ & 555 & 21 & $\mathrm{G}$ & Kiltașı & Alt orta yamaç & 12 & 9,03 & 5,25 \\
\hline $3-1$ & 562 & 23 & GB & Ofiyolitik melanj & Alt orta yamaç & 10 & 10,01 & 6,13 \\
\hline $3-2$ & 542 & 25 & GB & Ofiyolitik melanj & Alt orta yamaç & 10 & 9,88 & 5,70 \\
\hline $3-3$ & 535 & 27 & GB & Ofiyolitik melanj & Alt orta yamaç & 10 & 9,40 & 5,09 \\
\hline $4-1$ & 385 & 36 & $\mathrm{D}$ & Kiltaşı & Alt yamaç & 13 & 7,09 & 4,59 \\
\hline $4-2$ & 391 & 36 & $\mathrm{D}$ & Kiltaşı & Alt orta yamaç & 13 & 7,19 & 4,65 \\
\hline $4-3$ & 402 & 39 & $\mathrm{D}$ & Kiltaşı & Üst orta yamaç & 13 & 7,50 & 4,31 \\
\hline $5-1$ & 391 & 32 & GD & Kiltaşı & Alt orta yamaç & 7 & 11,21 & 7,14 \\
\hline $5-2$ & 398 & 32 & GD & Kiltaşı & Üst orta yamaç & 7 & 9,96 & 7,81 \\
\hline $5-3$ & 418 & 33 & GD & Kiltaşı & Üst orta yamaç & 7 & 9,97 & 7,09 \\
\hline $6-1$ & 364 & 23 & $\mathrm{D}$ & Kumtaş1-Konglomare & Alt yamaç & 19 & 5,33 & 3,45 \\
\hline $6-2$ & 355 & 3 & $\mathrm{D}$ & Kumtaş1-Konglomare & Alt yamaç & 19 & 4,49 & 2,97 \\
\hline $6-3$ & 353 & 3 & $\mathrm{D}$ & Kumtaş1-Konglomare & Sirt düzlüğü & 19 & 5,26 & 3,23 \\
\hline $7-1$ & 370 & 16 & $\mathrm{D}$ & Kiltaşı-Kumtaşı-Koglomera & Alt orta yamaç & 8 & 3,30 & 2,80 \\
\hline $7-2$ & 364 & 20 & $\mathrm{D}$ & Kiltaș-Kumtaș1-Koglomera & Alt orta yamaç & 8 & 2,34 & 2,90 \\
\hline $7-3$ & 368 & 25 & $\mathrm{D}$ & Kiltaşı-Kumtaş1-Koglomera & Alt orta yamaç & 8 & 1,83 & 2,59 \\
\hline
\end{tabular}


Çizelge 2. Örnek alanlara ilişkin bazı topraközellikleri $(0-30 \mathrm{~cm}$ derinlik kademesi için)

\begin{tabular}{|c|c|c|c|c|c|c|c|c|c|}
\hline Toprak no & $\begin{array}{c}\text { Org C } \\
(\%)\end{array}$ & $\begin{array}{c}\text { Toplam N } \\
(\%)\end{array}$ & $\begin{array}{c}\text { Kireç }\left(\mathrm{CaCO}_{3}\right) \\
(\%)\end{array}$ & $\mathrm{pH}\left(\mathrm{H}_{2} \mathrm{O}\right)$ & $\mathrm{pH}(\mathrm{KCl})$ & $\begin{array}{c}\text { Kum } \\
(\%)\end{array}$ & $\begin{array}{l}\text { Kil } \\
(\%)\end{array}$ & $\begin{array}{l}\text { Toz } \\
(\%)\end{array}$ & Toprak türü \\
\hline $1-1$ & 1,027 & 0,115 & 0,00 & 7,28 & 6,90 & 79,1 & 8,7 & 12,2 & $\overline{\mathrm{KuB}}$ \\
\hline $1-2$ & 0,869 & 0,113 & 0,15 & 7,12 & 6,37 & 70,9 & 18,9 & 10,2 & KuKB \\
\hline $1-3$ & 0,949 & 0,092 & 0,09 & 7,65 & 7,39 & 74,6 & 14,7 & 10,7 & $\mathrm{KuB}$ \\
\hline $2-1$ & 2,255 & 0,173 & 0,17 & 7,35 & 6,90 & 37,4 & 37,8 & 24,8 & BK \\
\hline $2-2$ & 1,969 & 0,194 & 0,24 & 7,62 & 7,33 & 33,7 & 29,4 & 36,9 & BK \\
\hline $2-3$ & 1,189 & 0,154 & 4,95 & 7,84 & 7,64 & 35,7 & 52,0 & 12,3 & $\mathrm{~K}$ \\
\hline $3-1$ & 0,535 & 0,099 & 0,08 & 7,36 & 6,49 & 64,6 & 26,8 & 8,6 & $\mathrm{KuK}$ \\
\hline $3-2$ & 1,151 & 0,108 & 5,61 & 8,00 & 7,71 & 41,9 & 29,0 & 29,1 & BK \\
\hline $3-3$ & 1,042 & 0,075 & 1,27 & 8,03 & 7,69 & 62,6 & 22,7 & 14,7 & KuKB \\
\hline $4-1$ & 2,727 & 0,150 & 4,92 & 7,91 & 7,49 & 45,8 & 28,7 & 25,5 & BK \\
\hline $4-2$ & 1,594 & 0,101 & 14,31 & 8,08 & 7,65 & 41,8 & 30,7 & 27,5 & BK \\
\hline 4- 3 & 1,949 & 0,127 & 11,64 & 8,03 & 7,54 & 41,8 & 32,7 & 25,5 & BK \\
\hline $5-1$ & 1,087 & 0,072 & 40,58 & 8,05 & 7,67 & 30,5 & 28,5 & 41,0 & BK \\
\hline $5-2$ & 0,558 & 0,079 & 34,71 & 8,04 & 7,71 & 45,0 & 24,4 & 30,6 & $\mathrm{~KB}$ \\
\hline $5-3$ & 2,204 & 0,112 & 16,92 & 7,98 & 7,56 & 51,0 & 24,4 & 24,6 & $\mathrm{~KB}$ \\
\hline $6-1$ & 0,806 & 0,059 & 30,49 & 8,00 & 7,66 & 77,5 & 20,4 & 2,1 & KuKB \\
\hline $6-2$ & 1,171 & 0,064 & 30,45 & 8,14 & 7,67 & 66,9 & 24,8 & 8,3 & KuKB \\
\hline $6-3$ & 0,359 & 0,026 & 32,85 & 8,06 & 7,68 & 67,7 & 10,5 & 21,8 & $\mathrm{KuB}$ \\
\hline $7-1$ & 0,877 & 0,025 & 34,71 & 8,03 & 7,59 & 34,9 & 31,0 & 34,1 & BK \\
\hline $7-2$ & 1,708 & 0,114 & 27,24 & 8,13 & 7,68 & 42,6 & 25,1 & 32,3 & BK \\
\hline $7-3$ & 1,251 & 0,055 & 30,83 & 8,08 & 7,62 & 44,9 & 25,0 & 30,1 & $\mathrm{~KB}$ \\
\hline
\end{tabular}

K: Kil, BK: Balçıklı kil, KuK: Kumlu kil, KB: Killi balçık, KuKB: Kumlu killi balçık, KuB: Kumlu balçık

\subsection{Istatiksel değerlendirme sonucunda elde edilen bulgular}

Duncan testi sonucuna göre, göğüs yüksekliği çap1 (kabuksuz) değerlerine göre 4 grup oluşmuş; 1. grupta; 7, 2. grupta; 6-1, 3. grupta; 4-2, 4. grupta; 3-5 nolu doğal gençleştirme sahas 1 yer almıştır. Boy değerlerine göre ise 6 grup oluşmuş olup; 1 . grupta; 7, 2. grupta; 6,3 . grupta; 1-4, 4. grupta; 4-2, 5. grupta; 3, 6. Grupta; 5 nolu doğal gençleştirme sahası yer almıştır (Çizelge 3).

Kızılçam doğal gençleştirme sahalarındaki ağaç çap ve boy gelişimi üzerinde toprak özelliklerinin etkisini belirlemek amaciyla yapılan korelasyon analizi sonucuna göre göğüs yüksekliği çap1 ve ağaç boyu ile toprak özellikleri arasında istatistiki anlamda herhangi bir ilişki bulunamamıştır. Gögüs yüksekliği çapı ile boy arasında $\% 1$ önem seviyesinde $\left(r^{2}=0,916 / p=0,000\right)$ pozitif yönlü iliş ki bulunmuştur. Organik karbon ile azot arasında \%1 önem seviyesinde $\left(\mathrm{r}^{2}=0,688 / \mathrm{p}=0,001\right)$ pozitif yönlü, kum miktarı aras inda \%5 önemseviyesinde $\left(\mathrm{r}^{2}=-0,468 / \mathrm{p}=0,032\right)$ negatif yönlü bir ilişki bulunmuştur. Toplam azot ile kireç arasında $\% 1$ önem seviyesinde $\left(r^{2}=-0,700 / p=0,000\right)$ negatif yönlü, aktüel asitlik arasında $\% 5$ önem seviyesinde $\left(r^{2}=-0,464\right.$ / $\mathrm{p}=0,034)$ negatif yönlü, kil miktarı arasında $\% 5$ önem seviyesinde $\left(r^{2}=0,461 / p=0,35\right)$ pozitif yönlü bir ilişki bulunmuş̧ur. Kireç ile aktüel asitlik arasında \%1 önem seviyesinde $\left(r^{2}=0,697 / p=0,000\right)$ pozitif yönlü, potansiyel asitlik arasinda \%1 önem seviyesinde $\left(\mathrm{r}^{2}=0,588 / \mathrm{p}=0,05\right)$ pozitif yönlü bir ilişki bulunmuştur. Aktüel asitlik ile potansiyel asitlik aras inda \%1 önem seviyesinde $\left(\mathrm{r}^{2}=0,942\right.$ / $\mathrm{p}=0,000)$ pozitif yönlü bir ilişki bulunmuştur. Kum ile kil arasında \%1 önem seviyesinde $\left(\mathrm{r}^{2}=-0,751 / \mathrm{p}=0,000\right)$ negatif yönlü, tozaras inda \% 1 önem seviyesinde $\left(r^{2}=-0,829\right.$ $/ p=0,000$ ) negatif yönlü iliş kiler bulunmuştur (Çizelge 4).

\section{Tartıșma ve sonuçlar}

Yapmış olduğumuz çalışmada da toprak parametreleri ile ağaçların gelişimi (çap-boy değerleri) arasında istatis tiki açıdan bir ilişki bulunamamıştır. Özkan ve Kuzugedenli
(2010), tarafindan yapılan "Akdeniz Bölgesi Sütçüler Yöresi'nde kızılçamın (Pinus brutia Ten.) verimliliği ile yetişme ortamı özellikleri arasındaki ilişkiler" konulu çalışmada çalışmamıza benzer şekilde; bonitet endeksi ile bağımsı değişkenler (bakı, yamaç konumu, denizden yüksekli, eğim, toprak derinliği, genel taşlllı, iskelet miktarı, pH, kireç, organik madde, kil, toz, kum, üst boy) arasinda yapilan basit regresyon analizi sonucunda toprak özellikleri ile ağaç boyu arasında ilişki bulunamamış olup sadece, denizden yükseklik ile üst boy arasında önemli negatif ilişki bulunmuştur. Çalış mamız sonuçlarına benzer olarak Çelik ve Özkan (2015), tarafindan yapılan bir başka çalışmada da kızılçamın yetişme ortamı özellikleri ile ikili ilişkileri araştırmak için yapılan korelasyon analizi sonucunda hiç bir yetişme ortamı özelliği ile istatistiks el olarak önemli bir iliş ki tespit edilememiştir.

Fizyolojik derinlik orman ağaçlarının gelişimi bakımından mutlak derinliğe göre çoğu zaman daha ön plan çıkmaktadır. Tortul kayaç ve materyallerde fizyolojik derinlik anakayanın çatlak yapısı tortul materyallerin istiflenme şekline göre değişkenlikler gösterebilmektedir. Toprak özellikleri ile ağaç gelişimi arasında istatistiki açıdan bir ilişki bulunamamasının ana sebebi çalışma alanımızda ağaç gelişiminde etkin olan ana faktörün fizyolojik derinlik olması ile açıklanabilir. Fizyolojik derinlik değerini sayısallaştırmak oldukça güç olduğu için fizyolojik derinlik ile ağaç gelişimi arasındaki ilişki is tatis tiki olarak araştırılamamıştır.

Ağaç gelişiminin en iyi olduğu saha 5 nolu saha olarak belirlenmiştir. $\mathrm{Bu}$ sahada ağaç gelişiminin iyi olması fizyolojik derinliğ in pek derin olduğ sahada yapılan profil incelemesinde blok kaya gözlemlenmemesine bağlı olarak pedondaki toprak miktarının fazla olması ve toprağın killi balçık türde olması ile açıklanabilir. Karatepe vd. (2005), tarafindan yapılan Isparta Gölcük Tabiat Parkı'nda Toros sediri (Cedrus libani A. Rich.)'nin Farklı Anakayalardan Oluşmuş Topraklardaki Gelişiminin Ekolojik İrdelenmesi baş lıklı çalışmada da, Toros sedirinin en iyi boy büyümesi ve çap artımını çalışmamıza benzer şekilde pedondaki toprak miktarının en çok olduğu alüvyon topraklarında 
yaptığını tespit etmişlerdir. Özkan vd. (2008), tarafindan Beyşehir Gölü Havzası'nda, Karaçam(Pinus nigra Arn. ssp. pallasiana) ormanlarında yapılan çalışmada da ağaç büyümesinin, derinliğe bağlı olarak aşağı yamaçlara inildikçe arttığını tespit etmişlerdir. Bu sonuçta aşağı yamaçlarda derinliğe ilaveten birim hacimdeki (pedondaki) toprak miktarının artışı ile açıklanabileceğinden 5 nolu sahadaki tes pitimize benzerlik göstermektedir.

Gelişimin 2. olarak en iyi olduğu sahan 3 numaralı saha olarak belirlenmiştir. $\mathrm{Bu}$ sahada fizyolojik derinliğin pek çok yerde $120 \mathrm{~cm}$ 'nin altına inebildiği gözlemlenmiştir. Sahada yapilan profil incelemesinde profil boyunca yer yer kaya blokları gözlemlenmiştir. Bu durum 5 numaralı sahaya göre pedon içerisindeki toprak miktarını azaltmış olup, bu sebeple de ağaç gelişimi bes in ve özelliklede su tutumunun 5 numaralı sahaya göre daha az olması sebebiyle daha geride kalmış olabilir. Quezell (1977) tarafından yapılan çalışmada da son derece kanaatkar olan kızılçamın iyi gelişim gösterebilmesinin anakayanın çatlak yapısı dolayısıyla fizyolojik derinlikle ilişkili olduğu belirtilmektedir.

Ağaç gelişimin 3. ve 4. olarak en iyi olduğu sahalar sırasıyla 2 ve 1 numaralı sahalar olarak belirlenmiştir. $\mathrm{Bu}$ sahalarda fizyolojik derinlik yer yer $120 \mathrm{~cm}$ 'yi bulsa da genel olarak 50-60 cm civarında gözlemlenmiştir. Fizyolojik derinliğ in 5 ve 3 numaralı sahalara göre genel olarak daha az oluşu gelişimin bu iki sahaya göre daha az olmasının nedeni olarak gösterilebilir. Bu iki sahadan 2 numaralı sahada gelişimin daha iyi olması sahadaki taban suyu yüksekliğinin yanı sıra kil oranındaki yüksekliğe bağ $h_{1}$ olarak toprağın su besin tutma kapasitesinin daha iyi olması ile açıklanabilir.

Çizelge 3. Göğüs yüksekliği çapı ve boy değerlerinin Duncan testi sonuçları

\begin{tabular}{|c|c|c|c|c|c|c|c|c|c|c|c|}
\hline \multicolumn{6}{|c|}{ Cap (cm) } & \multicolumn{6}{|c|}{ Boy (m) } \\
\hline Saha no & Ağaç sayısı & Grup 1 & Grup 2 & Grup 3 & Grup 4 & Grup 1 & Grup 2 & Grup 3 & Grup 4 & Grup 5 & Grup 6 \\
\hline 7 & 30 & 2,490 & & & & 2,767 & & & & & \\
\hline 6 & 30 & & 5,030 & & & & 3,210 & & & & \\
\hline 1 & 30 & & 5,707 & & & & & 4,417 & & & \\
\hline 4 & 30 & & & 7,267 & & & & 4,520 & 4,520 & & \\
\hline 2 & 30 & & & 7,957 & & & & & 4,813 & & \\
\hline 3 & 30 & & & & 9,763 & & & & & 5,643 & \\
\hline 5 & 30 & & & & 10,377 & & & & & & 7,347 \\
\hline
\end{tabular}

Çizelge 4. Gögüüs çapı yüks ekliğive boy ile topraközellikleri arasındaki ilişkiler (n=21)

\begin{tabular}{|c|c|c|c|c|c|c|c|c|c|c|c|}
\hline & & $\begin{array}{l}\text { Gögüs yükssekliği } \\
\text { çapı }(\mathrm{cm})\end{array}$ & $\begin{array}{l}\text { Boy } \\
\text { (m) }\end{array}$ & $\begin{array}{c}\text { Organik C } \\
(\%)\end{array}$ & $\begin{array}{c}\text { Toplam } \mathrm{N} \\
(\%)\end{array}$ & $\begin{array}{c}\text { Kireç } \\
(\%)\end{array}$ & $\begin{array}{c}\mathrm{pH} \\
\left(\mathrm{H}_{2} \mathrm{O}\right)\end{array}$ & $\begin{array}{c}\mathrm{pH} \\
(\mathrm{KCl})\end{array}$ & $\begin{array}{l}\text { Kum } \\
(\%)\end{array}$ & $\begin{array}{l}\text { Kil } \\
(\%)\end{array}$ & $\begin{array}{l}\text { Toz } \\
(\%)\end{array}$ \\
\hline \multirow{2}{*}{$\begin{array}{l}\text { Gögüus yüksekliği } \\
\text { çap1 }(\mathrm{cm})\end{array}$} & \multirow{3}{*}{$\begin{array}{l}\text { Korelasyon } \\
\text { katsayis1 } \\
\text { p değeri } \\
\text { Korelasyon }\end{array}$} & \multirow[t]{2}{*}{1} &, $916^{* * *}$ &, 032 &, 311 &,- 272 &,- 080 &,- 027 &,- 220 & ,276 & ,088 \\
\hline & & &, 000 & 889 &, 171 & ,233 & ,729 & ,906 & ,338 & ,226 & ,703 \\
\hline \multirow{2}{*}{ Boy (m) } & &, $916^{* *}$ & 1 &,- 004 &, 246 &,- 136 &,- 092 &,- 048 &,- 216 &, 155 &, 184 \\
\hline & p değeri &, 000 & & ,985 &, 282 &, 558 & 693 & ,838 &, 348 &, 501 & ,424 \\
\hline \multirow{2}{*}{ Organik C $(\%)$} & $\begin{array}{l}\text { Korelasyon } \\
\text { katsayis1 }\end{array}$ &, 032 &,- 004 & 1 &, $688^{* *}$ &,- 302 &, 035 &, 070 &,$- 468^{*}$ &, 396 &, 350 \\
\hline & $\mathrm{p}$ değeri & ,889 & ,985 & & 001 &, 184 &, 881 &, 764 & ,032 &, 076 &, 120 \\
\hline \multirow{2}{*}{ Toplam N (\%) } & $\begin{array}{l}\text { Korelasyon } \\
\text { katsayis1 }\end{array}$ & ,311 & ,246 &, $688^{* *}$ & 1 &,$- 700^{* *}$ &,$- 464^{*}$ &,- 333 &,- 334 &, $461^{*}$ & ,097 \\
\hline & $\mathrm{p}$ değeri &, 171 & ,282 &, 001 & &, 000 &, 034 &, 140 & ,139 & 035 & ,674 \\
\hline \multirow{2}{*}{ Kireç (\%) } & $\begin{array}{l}\text { Korelasyon } \\
\text { katsayis1 }\end{array}$ &,- 272 &,- 136 &,- 302 &,$- 700^{* * *}$ & 1 &, $697^{* *}$ &, $588^{* * *}$ &,- 180 &,- 102 &, 351 \\
\hline & p değeri &, 233 &, 558 &, 184 &, 000 & & ,000 & ,005 &, 434 & 660 &, 119 \\
\hline \multirow[t]{2}{*}{$\mathrm{pH}\left(\mathrm{H}_{2} \mathrm{O}\right)$} & $\begin{array}{l}\text { Korelasyon } \\
\text { katsayis1 }\end{array}$ &,- 080 &,- 092 &, 035 &,$- 464^{*}$ &, $697^{* *}$ & 1 &, $942^{* * *}$ &,- 338 &, 140 & ,377 \\
\hline & p değeri &, 729 & 693 &, 881 &, 034 &, 000 & & ,000 &, 134 &, 545 & ,092 \\
\hline \multirow[t]{2}{*}{$\mathrm{pH}(\mathrm{KCl})$} & $\begin{array}{l}\text { Korelasyon } \\
\text { katsayss1 }\end{array}$ &,- 027 &,- 048 &, 070 &,- 333 &, $588^{* *}$ &, $942^{* *}$ & 1 &,- 349 &, 160 & ,376 \\
\hline & $\mathrm{p}$ değeri & ,906 &, 838 &, 764 &, 140 &, 005 &, 000 & &, 121 & ,490 & 093 \\
\hline \multirow[t]{2}{*}{$\operatorname{Kum}(\%)$} & $\begin{array}{l}\text { Korelasyon } \\
\text { katsays1 }\end{array}$ &,- 220 &,- 216 &,$- 468^{*}$ &,- 334 &,- 180 &,- 338 &,- 349 & 1 &,$- 751^{* * *}$ &,$- 829^{* *}$ \\
\hline & $\mathrm{p}$ değeri & ,338 & ,348 &, 032 & ,139 &, 434 & ,134 &, 121 & &, 000 & ,000 \\
\hline \multirow[t]{2}{*}{$\operatorname{Kil}(\%)$} & $\begin{array}{l}\text { Korelasyon } \\
\text { katsayis1 }\end{array}$ & ,276 &, 155 &, 396 & $461^{*}$ &,- 102 &, 140 &, 160 &,$- 751^{* *}$ & 1 &, 253 \\
\hline & p değeri & ,226 &, 501 &, 076 &, 035 & ,660 &, 545 & ,490 &, 000 & & ,269 \\
\hline \multirow[t]{2}{*}{ Toz $(\%)$} & $\begin{array}{l}\text { Korelasyon } \\
\text { katsayis1 }\end{array}$ & ,088 &, 184 &, 350 & ,097 &, 351 &, 377 &, 376 &,$- 829^{* *}$ &, 253 & 1 \\
\hline & $\mathrm{p}$ değeri &, 703 & ,424 &, 120 & 674 & , 119 & 092 & ,093 &, 000 & ,269 & \\
\hline
\end{tabular}

*** $<<0,01$ ve * $\mathrm{p}<0,05$ 'i göstermektedir. 
Ağaç gelişimin en kötü olduğu saha 7 numaralı saha olarak tespit edilmiş tir. Bu sahada anakayanın yatay tabakah tortul bloklardan oluşması fizyolojik derinliği çok azaltmıştır. Anakaya ağırlıklı olarak kiltaşı ve daha az miktarda da kumtaşı, ince çakıltaşı ve konglomeradan oluşmaktadır. Bu sahada ağaç gelişiminin kötü oluşu tortul tabakaların yeryüzüne paralel uzanması sebebiyle ağaçların aşağ1 doğu kök gelişimini rahat yapamaması ile açıklanabilir. Çalışmamızdaki gelişiminin en kötü olduğu 7 numaralı sahadaki anakaya yapısının büyüme üzerindeki olumsuzluklarını destekler nitelikte bazı araştırma sonuçları bulunmaktadır. Şöyle ki; Şad (1976), yaptığ kompakt metamorfik kayaçlar üzerinde kızılçamın yetişmediğini belirtmiş tir. Anakayanın, kök nüfuzuna imkân verebilecek yeterlilikte çatlaklı olup olmaması ve tabakalanma biçimi, kızılçamın gelişmesinde anakayanın türünden daha önemli gibi görünmekte olup, çatlaklı olmayan kalker ve travertenler ile toprak yüzeyine paralel tabakalanış gösteren fliş ler üzerinde ya hiç gelişmemekte ya da çok zayıf bir gelişim gösterebildiğ ini ifade etmiştir.

A ğaç gelişiminin 2.olarak en kötü olduğu saha 6 numaralı saha olarak tespit edilmiştir. $\mathrm{Bu}$ sahada ise anakayanın kalın yataya yakın tabakalı kumtaşı ve sert yapılı konglomera oluşu fizyolojik derinlik yer yer uygun olsa da yoğun miktardaki iskelet miktarı sebebiyle su ve besin tutumunu azaltmıştır. Bu durum ağaç gelişiminin kötü oluşunun sebebi olarak gösterilebilir. Polat vd. (2014), tarafından yapılan bir çalışmada da, çalışmamızdaki 6 numaralı saha sonuçlarına benzer olarak taşlilığın fazla olduğu araş tırma sahalarında is kelet hacmindeki artış in sedir ve karaçam üst boyuna olumsuz etki yapmakta olduğu belirtilmiştir.

Ağaç gelişiminin 3.olarak en kötü olduğu saha 4 numaralı saha olarak tes pit edilmiş tir. Bu sahada anakayanın karışık tabakalanma gösteren kiltaşıdır. A ğaç gelişiminin bu sahada kötü oluşunun sebebi tabakaları yoğun istifli yapısı sebebiyle kök gelişimi zorlaştırması ve iskelet içeriğinin \% 75 'in üzerinde oluşu ile açıklanabilir.

Sonuç olarak tortul kayaç ve anamateryal yapısının hakim olduğu sahalarda fizyolojik derinlik oldukça değişken olup, fizyolojik derinlik durumuna göre ağaç gelişimleri değişmektedir. Bu sebeple bu tip sahalarda yapılacak suni tensil, tabii tensil ve ağaçlandırma çalışmaları öncesinde yapılacak etüd çalışmalarında özellikle bu durum göz önünde bulundurulmalıdır. Mutlak toprak derinliğini az bile olsa şayet fizyolojik derinlik uygun ise gelişimin çok iyi olabileceği dikkatten kaçırılmamalıdır.

\section{Teşekkür}

$\mathrm{Bu}$ çalışma Süleyman Demirel Üniversitesi Bilimsel Araştırma Projeleri Yönetim Birimi tarafindan 3961-YL114 No`lu, "Isparta Orman Bölge Müdürlüğü kızılçam (Pinus brutia Ten.) doğal gençleştirme sahalarında anakaya toprak özelliklerinin ağaç gelişimine etkisi” isimli proje ile desteklenen yüksek lisans tezinin özeti olup, katkılarından dolayı Süleyman Demirel Üniversitesi Bilimsel Araştırma Projeleri Yönetim Birimi’ne teşekkür ederiz.

\section{Kaynaklar}

Anonim, 2012. Türkiye Orman Varlığ1. Orman Genel Müdürlüğü, Orman İdaresi ve Planlama Dairesi Başkanlığı Yayın No: 85, Ankara.

Asmaz, H., 1993. Akdeniz peyzajında kızılçamın önemi. Ulus lararası Kızılçam Sempozyumu, 18-23 Ekim 1993, Bildiriler Kitab1, s.48-55, Marmaris.

Atalay, İ., 1983. Türkiye Vejetasyon Coğrafyas ına Giriş. E. Ü. Edebiyat Fak. Yay. No:19.

Atalay, İ., Sezer, İ., Çukur, H., 1998. Kızılçam (Pinus brutia Ten.) Ormanlarının Ekolojik Özellikleri Ve Tohum Nakli Açısından Bölgelere Ayrılması. Orman Ağaçları ve Tohumları Islah Araştırma Müdürlüğü, Yayın No.6, 108 s., Ege Üniversitesi Basım Evi, İzmir.

Çelik, H., Özkan, K., 2015. Antalya Ovacık Dağ1 Yöresi'nde kızılçam (Pinus brutia Ten.)'n gelişimi ile yetişme ortamı özellikleri arasındaki ilişkiler. SDÜ Fen Bilimleri Enstitüsü Dergisi, 19(2):190-197.

Kantarc1, M.D., 1982. Akdeniz Bölgesinde Doğal Ağaç ve Çalı Türlerinin Yayılışı ile Bölgesel Yetişme Ortamı Özellikleri Arasındaki İlişkiler. İ.Ü. Orman Fakültesi Yayın1, No. 3054/330, s.105, İstanbul.

Kantarc1, M.D., 1984. Türkiye'nin Batı Akdeniz Bölümündeki kızılçam ağaçlandırmalarında ekolojik değerlendirmeler. İ.Ü. Orman Fakültesi Dergisi Seri: A, Cilt: $2,81-100$.

Karaöz, M.Ö., 1989a. Toprakların su ekonomisine ilişkin bazı fiziksel özelliklerinin laboratuvarda belirlenmesi yöntemleri. İstanbul Üniversitesi, Orman Fakültesi Dergisi, 39(2):133-144.

Karaöz, M.Ö., 1989b. Toprakların bazı kimyasal özelliklerinin ( $\mathrm{pH}$, karbonat, tuzluluk, organik madde, total azot, yararlanılabilir fosfor) analiz yöntemleri. İstanbul Üniversitesi, Orman Fakültesi Dergisi, 39(3): 64-82.

Karatepe, Y., 2004. Eğirdir Gölü Havzas ının yetişme ortamı özellikleri ve sınıflandırılması. Doktora Tezi, İstanbul Üniversitesi, Fen bilimleri Enstitüsü, İstanbul.

Karatepe, Y., Süel, H., Yetüt, İ., 2005. Isparta Gölcük Tabiat Parkı'nda Toros sediri (Cedrus libani A. Rich.)'nin farklı anakayalardan oluşmuş topraklardaki gelişiminin ekolojik irdelenmesi. SDÜ. Orman Fakültesi Dergisi, Seri A, 1: 64-75.

Kayacık, H., 1965. Orman ve Park Ağaçlarının Özel Sistematiği Gymnospermae (Açık Tohumlular) I. Cilt. İstanbul Üniversitesi Orman Fakültesi Yayın No: 1105/98, 390s. İstanbul.

Neyişçi, T., 1987a. Kızılçamın doğal yayılışı. Kızılçam, El Kitabı Dizisi 2, OAE Yayını, Muhtelif Yayınlar Serisi, No. 52, 15-22.

Neyişçi. T., 1987b. Kızılçamın ekolojisi. E. Öktem (ed), Kızılçam, Ormancılık Araştırma Enstitüsü Yayınları, El Kitab1 Dizisi 2, s. $23-56$.

Özkan, K. Gülsoy, S, Mert, A., 2008. Interrelations between height growth and site characteristics of Pinus nigra Am. ssp. pallasiana (Lamb.) Holmboe. J. The Malaysian Forester, 71: 9-17. 
Özkan, K., Kuzugüdenli, E., 2010. Akdeniz Bölgesi Sütçüler Yöresinde kızılçamın (Pinus brutia Ten.) verimliliği ile yetişme ortamı özellikleri arasındaki ilişkiler. Süleyman Demirel Üniversitesi Orman Fakültesi Dergisi, Seri: A, 1:16-29.

Quezell, P., 1977. Forest of the Mediterranean Basin in Mediterranean Forest and Maquis: Ecology, Conservation and Management, MAB Technical Notes: 2.

Pantelas, V., 1986. The Forests of Brutia Pine in Cyprus. Ciheam, 86(1): 43-46.

Polat, S., Polat, O., Kantarc1, M.D., Tüfekçi, S., Aksay, Y., 2014. Mersin-Kadınck Havzası'ndaki sedir (Cedrus libani A. Rich.) ve karaçam (Pinus nigra Arnold.) ağaçlandırmalarının boy gelişimi ile bazı yetişme ortamı özellikleri arasındaki ilişkiler. Ormancılık Araştırma Dergisi, Cilt:1(A): 22-37.
Saatçioğlu, F., Pamay, B., 1962. Adana bölgesinin kalkınmasında kızılçamın (Pinus brutia Ten.) önemi ve silvikültürü. İ.Ü. Orman Fakültesi Dergisi, Seri A, Cilt XII, Say1: 2:88-101.

Şad, H.C., 1976. Türkiye'de Reçine Üretimi Yapılan Ormanların Amenajman Esasları Hakkında Araştırmalar. İÜ Orman Fakültesi, Yayın No: 214, İstanbul.

Şenel, M., 1997. MTA Türkiye Jeoloji Haritası, Isparta 4 Paftas1, 1:250000 No: 14. Jeoloji Etütleri Dairesi, Ankara. 